\title{
The Impact Of Using Music On Teaching English Poetry In Jordanian Universities
}

Dima Hijazi, Yarmouk University, Irbid, Jordan

Amal Al-natour, Yarmouk University, Irbid, Jordan

\begin{abstract}
The purpose of this study is to investigate the impact of using music on teaching English Poetry in Jordanian universities on students' performance. The researchers followed the equivalent pre/post $T$ test two group designs. To achieve the aim of the study, a pre/post-test was constructed to measure students' performance in English poetry. The sample of this study consisted of 120 students (56 males and 64 females) from the third year students in Al Zaytoonah University during the first semester of the academic year 2011/2012. The subjects of the study were distributed into two groups (experimental group and control group). The experimental group was taught poetry accompanied with music while the control group was taught poetry using the traditional way of teaching. The subjects were 30 male students for the experimental group and 26 male students for the control group, while the female students for the experimental and control group were 31 and 33 respectively. Those subjects were distributed into two purposefully selected sections in Al Zaytoonah University in Amman. Descriptive statistical analyses were used (means and standard deviation) for the pre and post- tests of students' poetry test to experimental and control groups. Comparison statistical methods were used (Two Way ANOVA) analysis of variance to make a comparison between the control and the experimental groups and gender variable (male and female). The findings of the study indicated that there were statistically significant differences in the post- test between the control and the experimental groups in favor of the experimental group, and there was no statistically significant difference in the students' achievement due to gender. There was no statistically significant difference due to the interaction between gender and group. The researchers proposed some recommendations to enhance the effect of using music in teaching poetry on students' performance such as conducting further studies in other universities.
\end{abstract}

Keywords: Jordanian Universities; Using Music to Teach English Poetry

\section{INTRODUCTION}

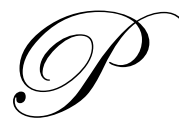

oetry plays a very important role in our lives. For example, it awakens our senses, connects us with ourselves and others, and leads us to think in synthesizing ways, as required by its use of the language of metaphor ( Zwicky, 2000; Peacock, 1999; Hoogland, 2011). Poetry's attraction is in its conciseness, its brevity, and its power to convey so much in a limited space. It offers depth in a moment which provides a quick dive in a deep pool as pointed out by Peacock (1999). Since language is for communication, poetry is considered as one of the best ways to express oral and written language.

Reading and writing poems can help us discover profound truths we didn't realize as indicated by Michaels (1999). Damico (2005) said that poetry provokes thoughts about complex social issues and evokes feelings. It requires and facilitates the concentration of mind or sustained attention to which our hectic lives have unaccustomed us since it is a way of knowing and a vehicle for expressing our thoughts and feelings. What makes poetry so powerful is that the way it links familiar images with strange ones. In addition, it transforms the way we see commonplaces.

The purpose of using music in the adult EFL classrooms is to create a learning environment by increasing vocabulary; building listening comprehension, enhancing speaking, reading, and writing skills and expanding 
cultural knowledge. Maess , Koelsch, Gunter, \& Friederici (2001) pointed out that musical and language processing appear in the same area of the brain which is parallel in how musical and linguistic syntax are processed.

Most classroom music activities focus on Lyrics. Murphy (1992) conducted an analysis of the lyrics of a large corpus of pop songs and he found that they have different features that help second language learners. They contain many personal pronouns and common, short words; the language is conversational; there is repetition of vocabulary and structures; time and place are usually imprecise; and the lyrics are often sung at a slower rate than words are spoken with more pauses between utterances. Murphey added that these factors allow learners to relate to the songs and understand them. Moi (1994) also stated another benefit of pop song lyrics that their meanings are fluid, and, like poetry, allow for many different interpretations.

Nevertheless, practicing the natural reductions that occur in spoken English and also a choral or individual reading of the lyrics of some songs can be benefited by students from any language background. The students can summarize the action or theme of a song orally or give oral presentations about a song or music or may play musical selections for the class. Response sheets can be filled out by students about each presentation. Moreover, they can answer questions about the featured topic, something new they learned, and something they enjoyed in order to involve the whole class which may also encourage group work and collaborative learning among students.

\section{SIGNIFICANCE OF THE STUDY}

Poetry seems to cause the most serious problems for students. This fact is asserted in many research papers such as Andrews (1991), Benton (1999), Benton (2000), Pike (2000) who pointed out that teaching poetry is more difficult to be taught than any other genres. Lockward, (1994) added that language arts teachers feel uncomfortable when teaching poetry, either because they aren't competent about teaching it appropriately (lack pedagogical role models), or because they find it ambiguous.

Teaching poetry through print text and finding one meaning to be dissected is the common model of poetry teaching, especially for older students. However, many poets asserted that hearing the poem accompanied with music, engaging with it, and probing for deeper meaning through discussion with others is very important in teaching poetry. Hughes (2006) indicated that we need to find meaningful ways to engage our students with poetry to expand their understanding in life and enrich their language fortune by enabling them to understand how literature (poetry in particular) and music complement each other.

\section{STATEMENT OF THE PROBLEM}

The topic of using music and song as pedagogical tools in the foreign language classrooms is very rare in research papers. Falioni (1993) pointed out that music in the classroom has been considered as a way of recreation and entertainment only, despite the fact that music's use in the foreign language classrooms has been of a great value. Students use songs in the classroom for enjoyment not for learning because they have often been met with laughter and admonitory statement. However, using music and songs while learning can enhance the process of learning if used with much more care. Dupuy (1997) indicated that Music is considered the pile of the foreign language curriculum. Honestly, the problem of this study is stemmed from the fact that there is a lack of empirical research papers using music in foreign language teaching especially in teaching English poetry. Thus, there is a critical need for empirical studies to be conducted in order to measure specific benefits of music and poetry teaching that may affect the prevailing attitude in the foreign language community. When a poem accompanied with music, it helps students to stir up a sensorial response by entertaining them and making them gain a better understanding of the meaning of the poem.

\section{PURPOSE OF THE STUDY}

The purpose of this study is to investigate the effect of using music on third year students' performance in English language poetry at $\mathrm{Al}$ Zaytoonah University. 


\section{QUESTIONS OF THE STUDY}

- $\quad$ Are there any statistically significant differences $(\alpha \leq 0,05)$ in the third year students' performance in English Language poetry due to the teaching strategies they are exposed to (using music and traditional way)?

- $\quad$ Are there any statistically significant differences $(\alpha \leq 0,05)$ in the third year students' performance in English Language poetry due to gender?

\section{LITERATURE REVIEW}

Using music in the second language classroom is very important. Songs are just like stories since they are considered as vehicles for second language acquisition so they should not be treated as extra-curricular entities (Medina, 1991). Moreover, accompanying music with poems is very useful, fun and low-cost that students may use different words and phrase structures and illustrations to make these words more comprehensible with the least cost lose. (Medina 1991).

Richards (1993) stated the emotional nature of music use in a playful teaching environment. She mentioned that music, rhythm, and movement create a relaxed, stress-free learning environment. She also discussed the cognitive uses of music, particularly for language acquisition purposes: the developments of auditory discrimination skills (such as syllabification, integration of letter sounds, and pronunciation of words) which are enhanced by music, are general classroom music activities that include singing and rhythm. It is noticed that many teachers have taken steps to bring music into the classroom despite its difficulties.

Beaton (1995) discussed the advantages of using music in the early childhood language classrooms such as giving students a love of culture, encouraging turn taking, improving their sensory awareness, and increasing improvisation skills. A child's anxiety is decreased and confidence is increased when chanting, singing, or clapping either in large circle groups or smaller group exercises. The study of Beaton in which two groups of children learned a grammatical concept in French, one group using traditional methods and the other using songs, proved that only the children who learned through songs could remember the grammar rules. Besides, Beaton mentioned that using group activities while teaching music can increase the quality of peer-to-peer learning. This benefit can collectively exert a deep effect on the overall learning outcome.

Wilcox (1995) investigated the effects of classroom singing among adult ESL students at a community college. She found that there were many benefits for using music in the classroom such as: improving pronunciation memory through organizational framework, linear time order, expectation, repetition, residual learning, lowering affective barriers, and anticipation of patterns, resolution cues, gestalt cues or schema, and anchors for memory. She indicated that the parallel structure of the song and lyrics prompted the students' memories. In other words, songs may enhance the practice of vocabulary through repeating their phrases and establish the prosody of the language in the classroom. Finally, she concluded that, if the students are not shy or reserved about participating in classroom activities, using songs for language learning could be more successful.

Schunk (1999) investigated the effectiveness of kinesthetic activity for language learning and the effect of singing and signing on elementary ESL students' acquisition of vocabulary. She found that they were effective. The sample consisted of four groups of twenty children who attended different training sessions, including 1) spoken text, 2) sung text, 3) spoken text paired with signs, 4) sung text paired with signs. The sample was given a pretest to check their vocabulary comprehension. A posttest was administered to determine the children's ability to identify gains in receptive vocabulary identification. The results showed that all four groups performed better in the posttest. There was a steady gain of vocabulary recognition among the groups one to four, but children who heard the text sung and watched the signs had a significantly higher gain over children who only heard the text spoken. The study revealed that music and movement enrichment of language teaching content became not an option, but a compelling next step in effectiveness.

Mora (2000) accepted the fact that music and language should be used in the EFL classrooms. She claimed that using verbal practices accompanied with musical information seems to be more memorable, that, foreign sounds 
paired with music will be stored in long-term musical memory and accessible for mental rehearsal and memorization. Moreover, using melody with new phrases lowers the student's anxiety. Repetition is considered as one of the main methods that makes the brain remembers material. Mora describes using a melodic approach as being vital, that is, using music has a great influence on the entire language acquisition process of EFL students and on their pronunciation skills. The musical method enhances the EFL learner's awareness of pauses, sounds, rhythms, and intonations. In addition, imitation and sub vocal rehearsal encourages them to develop linguistic fluency.

Learners should be put in an affective environment closer to that of first-language acquisition as asserted by the previous studies. A class is helped to be relaxing much like a family by songs. When musical contours are added by teachers to simplified language input, they can expect higher motivation and comprehension from learners. Cultural ideas are also made accessible to students and increase the capacity of the working memory by music, while providing a structured context for long-term recall of words and phrases.

\section{DESIGN AND METHODOLOGY}

The researchers discussed the procedures they used to conduct the study. They described the study population, sample, variables, instrument, procedures and the statistical analyses that were used in the study.

\section{POPULATION OF THE STUDY}

The population of the study consisted of:

All third year students at Al Zaytoonah University who are enrolled in the first semester 2011/2012, they were (2675) males and females.

\section{SAMPLE OF THE STUDY}

The sample of the study comprised of (120) third year students, they were 30 male students for the experimental group and 26 male students for the control group, while the female students for the experimental and control group were 31 and 33 respectively.

\section{DESIGN OF THE STUDY}

The participants of the study were divided into two groups, experimental and control. The participants of the experimental group were taught English poetry accompanied with music for (8) weeks, While the participants of the control group were taught using the traditional way for the same period. A pre-test was given before the application of the treatment to both groups to make sure they are equivalent and the same test was administered as a post-test after applying the treatment to see whether the using of music for teaching English poetry had any influence on the experimental groups and which strategy has more influence on the subjects than the other.

\section{INSTRUMENT OF THE STUDY}

The researchers used two strategies for teaching English poetry: A strategy by using music and the traditional strategy. Then, the researchers designed a test based on the instructional material of the third year English poetry course and collected the data. Validity and reliability were ensured. Both groups; the experimental group as well the control group, were taught by their instructor. The subjects in both groups took a pre-test to determine their actual level before starting the experiment, and the same test was administered as a post-test at the end of the experiment to assess subjects' achievement. The time interval between the pre-test and the post-test was (8) weeks; a period long enough to minimize the effect of the pre-test on the results and conclusions of the experiment.

\section{RELIABILITY OF THE INSTRUMENT}

To ensure the test reliability, the researcher followed test/retest technique. The researcher applied it to a pilot sample of (20) students who were excluded from the study with a two-week period between the test and the re- 
test. The reliability of the test was calculated using correlation coefficient and found to be 0.89 . This is appropriate for conducting such a study.

\section{VALIDITY OF THE INSTRUMENT}

The researchers validated the instrument by submitting it to a jury of two EFL professors teaching at Mutah University, and two professors at Al Zaytoonah University. The researchers asked the referees to write their comments if there are any.

\section{INSTRUCTIONAL MATERIAL}

The instructional material was the third year English poetry course which includes more than 22 poems, but the researchers will cover at least 3 poems during the application period.

\section{Procedures Of The Study}

There are two groups of students: one experimental group and one control group. Both groups received 8 weeks of instruction of English language poetry. Students in the experimental group were taught English poetry accompanied with music. While Students in the control group were instructed using the traditional way. The traditional instruction in this study was reading poems, memorize vocabulary, use of textbooks and other materials, and a clear explanation of the meaning of some words to students.

\section{STATISTICAL ANALYSES}

To answer the study questions, descriptive methods (means and standard deviations) were used for pre and post tests for English language vocabulary test for both the experimental and control groups.

In addition to a Two-Way ANOVA, the statistics used T- test to show equivalence, and Two- Way ANOVA to answer the research questions.

\section{FINDINGS OF THE STUDY}

The purpose of this study is to investigate the effect of using music for teaching English poetry on third year students' performance at $\mathrm{Al}$ Zaytoonah University. The researchers followed the equivalent pre /post test two group designs. Therefore, the means, standard deviations and Two-Way ANOVA analysis of variance were used to analyze data. The results are displayed based on the questions of the research.

To determine if there is a statistically significant difference between the male and the female groups, a ttest for independent samples was conducted. Table 1 shows the results.

Table 1: Means and Standard Deviations of the Achievement of Male and Female Groups on the Pretest

\begin{tabular}{|l|l|l|c|c|}
\hline \multirow{2}{*}{ Group } & \multicolumn{1}{|c|}{ Sex } & Mean & Std. Deviation & N \\
\hline \multirow{5}{*}{ Experimental } & Male & 54.07 & 6.602 & 30 \\
\cline { 2 - 5 } & Female & 54.71 & 8.719 & 31 \\
\cline { 2 - 5 } & Total & 54.39 & 7.693 & 61 \\
\hline \multirow{5}{*}{ Control } & Male & 54.65 & 7.467 & 26 \\
\cline { 2 - 5 } & Female & 53.55 & 6.815 & 33 \\
\cline { 2 - 5 } & Total & 54.03 & 7.069 & 59 \\
\hline \multirow{5}{*}{ Total } & Male & 54.34 & 6.958 & 64 \\
\cline { 2 - 5 } & Female & 54.11 & 7.754 & 6 \\
\cline { 2 - 5 } & Total & 54.22 & 7.364 & \\
\hline
\end{tabular}

Table 1 shows the mean and standard deviation of the groups on the pre-test. It shows the experimental group at 54.39. While the control group at 54.03. As for the males and females, the males were 54.34 and the female were 54.11 . 
To determine if the two groups are equivalent in their English vocabulary, a pre-test was conducted and Table 2 presents the results.

Table 2: Two-way ANOVA for the Results of the Experimental and Control Groups on the Pretest

\begin{tabular}{|l|c|c|c|c|c|}
\hline \multicolumn{1}{|c|}{ Source } & $\begin{array}{c}\text { Type III Sum of } \\
\text { Squares }\end{array}$ & df & Mean Square & F & Sig. \\
\hline Group & 2.478 & 1 & 2.478 & .045 & .833 \\
\hline Sex & 1.612 & 1 & 1.612 & .029 & .865 \\
\hline Group * Sex & 22.830 & 1 & 22.830 & .412 & .522 \\
\hline Error & 6424.320 & 116 & 55.382 & & \\
\hline Corrected Total & 6452.367 & 119 & & & \\
\hline
\end{tabular}

Based on the Two-way ANOVA on the pre-test, the groups were equivalent. Hence, level of significance is .833 which is not significant at $\alpha \leq 0,05$. Also the groups in terms of gender were equivalent at a level of .865 . This is not statistically significant at $\alpha \leq 0,05$. This means that the groups were equivalent on the pre-test.

At the end of the experiment, a T-test for independent samples was conducted to determine if there was any statistically significant difference between the males and the females on the posttest. Table 3 shows the results.

Table 3: Means and Standard Deviations of the Achievement of Male and Female Groups on the Posttest

\begin{tabular}{|l|l|c|c|c|}
\hline \multicolumn{1}{|c|}{ Group } & \multicolumn{1}{|c|}{ Sex } & Mean & Std. Deviation & N \\
\hline Experimental & Male & 84.57 & 8.253 & 30 \\
\hline & Female & 86.94 & 6.889 & 31 \\
\hline & Total & 85.77 & 7.621 & 61 \\
\hline Control & Male & 77.04 & 10.022 & 26 \\
\hline & Female & 78.48 & 11.843 & 33 \\
\hline Total & Total & 77.85 & 11.009 & 59 \\
\hline & Male & 81.07 & 9.794 & 56 \\
\hline & Female & 82.58 & 10.581 & 64 \\
\hline
\end{tabular}

Table 3 shows the means and standard deviations of the groups on the post-test. The experimental group was at 85.77 , while the control group was at 77.85. Males were 81.07 and females were 82.58 .

The researcher also conducted a two-way analysis of variance to analyze the posttest achievement scores of the two groups. Table 4 shows the results.

Table 4: Summary of the Two-way Analysis of Variance of the Achievement of the control and the Experimental Groups on the Post-test

\begin{tabular}{|l|c|c|c|c|c|}
\hline \multicolumn{1}{|c|}{ Source } & $\begin{array}{c}\text { Type III Sum of } \\
\text { Squares }\end{array}$ & df & Mean Square & F & Sig. \\
\hline Group & 1900.350 & 1 & 1900.350 & 21.199 & .000 \\
\hline Sex & 108.337 & 1 & 108.337 & 1.209 & .274 \\
\hline Group * Sex & 6.333 & 1 & 6.333 & .071 & .791 \\
\hline Error & 10398.442 & 116 & 89.642 & & \\
\hline Corrected Total & 12397.125 & 119 & & & \\
\hline
\end{tabular}

To answer the first question: Are there any statistically significant differences $(\alpha \leq 0,05)$ in the third year students' performance in English language poetry due to the teaching strategies they are exposed to (using music and traditional way)? The table shows that the level of significance is .000 which is statistically significant at $\alpha \leq 0$, 05 on favor of the experimental group. 
To answer the second question: Are there any statistically significant differences $(\alpha \leq 0,05)$ in the third year students' performance in English language poetry due to the gender? Table five shows significance .274 which means it is not significant at $(\alpha \leq 0,05)$.

To sum up, the researchers believe that the difference in the achievement of the third year students was attributed to the using of music for teaching English poetry. The experimental group subjects managed to significantly improve English vocabulary they already have in a period of 8 weeks. The improvement achieved by the control group subjects, however, was not statistically significant. By comparing the results achieved by the two groups, the researchers concluded that the improvement achieved by the experimental group may have been attributed to the way they rendered instruction; teaching poetry accompanied with music.

As a result of this experience, the researchers concluded that students were more engaged in learning when they were given a chance to listen to music accompanied with poems.

Furthermore, using music is a powerful tool with which students can learn English language poetry with entertainment.

\section{DISCUSSION}

As a conclusion, it is noticed that music and poetry can be studied together. Music can actively process new stimuli and infer the rules of language. It may code words with heavy emotional and contextual flags, evoke a realistic and cogent environment, and enable students to have positive attitudes, self-perceptions, and cultural appreciation. The most commonly known benefits for teaching poetry through music are that it can change the artificial classroom environment into a real experience and make new information meaningful, bringing interest and order to a classroom.

Instructors and teachers who teach poetry may gain a lot from familiarizing themselves with the research literature related to the uses of music and the effect of music on thought, behavior and the process of learning as a whole. The use of music for instruction in poetry is very important to focus on, that is, it takes little preparation to utilize songs for active class involvement, phrase and vocabulary acquisition, cultural appreciation, and pronunciation. Although poetry is rarely considered as an issue that music can benefit from, the results of this study showed the high benefits of music in teaching poetry especially vocabulary, pronunciation, grammar rules, language skills as well as lowering anxiety and increasing students' motivation towards learning English poetry. This result agrees with Wilcox (1995) and Mora (2000) who indicated that songs enhance the practice of vocabulary through repeating their phrases and establish the prosody of the language in the classroom. Moreover, it agrees with Richards (1993) who pointed that music, rhythm, and movement create a relaxed, stress-free learning environment.

Since the communicative approach is the best method followed in teaching in Jordan, the results of this study supported the principles of this approach that students are encouraged to work into poetry intuitively, not by memorizing poems and this issue is also asserted by Krashen (1982). Because there are individual differences among students since they are at different levels of competence, most instructors believe that using reading and memorizing strategies do not teach poetry as they intend to. On the other hand, teaching poetry though music decreases the individual differences among students and affects their learning positively.

\section{CONCLUSION}

It is clear that using music for teaching English poetry enhances students to study poems with entertainment and actually it improves their level in literature as they gain the skills of analysis and criticism in general. Learning English poetry is not easy for students who are studying English as a foreign language since native speakers of English language themselves face problems in learning it. So, it was found that using music may help students to comprehend poetry and enjoy analyzing it. 


\section{AUTHOR INFORMATION}

Deema Hijazi, Yarmouk University, Language Center, Ibid, Jordan. E-mail: Deemahijazi2233@yahoo.com Corresponding author.

Dr. Amal Al-natour, Yarmouk University, Language center, Irbid, Jordan, E-mail: Amal_natour13@yahoo.com

\section{REFERENCES}

1. $\quad$ Andrews,R. (1991). The problem with poetry. Milton Keyncs,UK: Open University Press.

2. Beaton (1995). The importance of music in the early childhood language curriculum. International Schools Journal, 15(1), 28-38.

3. Benton, P. (1999). Unweaving the rainbow: Poetry teaching in the secondary school I. Oxford Review of Education, 25(4), 521-531.

4. Benton, P. (2000). The conveyor belt curriculum? Poetry teaching in the secondary school II. Oxford Review of Education, 26(1), 81-93.

5. Damico, J. S. (2005). Evoking hearts and heads: Exploring issues of social justice through poetry. Language Arts, 83(2), 137-146.

Dupuy, B. (1997). Literature circles: An alternative framework for increasing intermediate FL students' comprehension of texts in the target language. Mosaic, 5(1), 13-16.

6. Falioni, J. W. (1993). Music as means to enhance cultural awareness and literacy in the foreign language classroom. Mid-Atlantic Journal of Foreign Language Pedagogy, 7, 97-108. (Eric Document Reproduction No. ED 355796$)$

7. Hoogland, C. (2011). Cognitive, affective and kinesthetic meaningmaking through the arts. Critical thinking: Teaching and testing in an era of educational accountability. London, ON: Althouse Press.

8. Hughes, J. (2006). Poets, poetry and new media: Attending to the teaching and learning of poetry. Unpublished doctoral dissertation. University of Western Ontario.

9. Krashen, S. (1982). Principles and practice in second language learning and acquisition. Oxford: Pergamon

10. Lockward, D. (1994). Poets on teaching poetry. English Journal, 83(5), 65-70.

Maess, B., Koelsch, S., Gunter, T. \& Friederici, A.D. (2001) . Musical syntax is processed in Broca's area: an MEG study. Nat. Neurosci. 4, 540-545 . | Article | PubMed | ISI | ChemPort

11. Medina, S.L. (1990). The effects of music upon second language vocabulary acquisition. Paper presented at the TESOL conference. San Francisco, CA. (Eric Document Reproduction Service No. ED352834)

12. Medina, S.L. (1991). The effect of a musical medium on the vocabulary acquisition of limited English speakers (Doctoral dissertation, University of Southern California, 1991). Dissertation Abstracts International, 52, 360.

13. Michaels, J. R. (1999). Risking intensity: Reading and writing poetry with high school students. Urbana, ILL: NCTE Press.

14. Moi, C. M. (1994). Rock poetry: The literature our students listen to. Journal of the Imagination in Language Learning, 2, 56-59.

15. Mora, C.F. (2000). Foreign language acquisition and melody singing. ELT Journal, 54(2), 146-152.

16. Murphey, T. (1992). The discourse of pop songs. TESOL Quarterly, 26(4), 770-774.

17. Peacock, M. (1999). How to read a poem ... and start a poetry circle. Toronto, ON: McClelland \& Stewart.

18. Pike, M. (2000). Keen readers: Adolescents and pre-twentieth century poetry. Educational Review, 52(1), $13-28$.

19. Richards, R.G. (1993). Music and rhythm in the classroom. In Learn: Playful techniques to accelerated learning, 109-113. (ERIC Document Reproduction Service No. ED379071)

20. Schunk, H. A. (1999). The effect of singing paired with signing on receptive vocabulary skills of elementary ESL students. Journal of Music Therapy, 36, 110-124.

21. Wilcox, W.B. (1995). Music cues from classroom singing for second language acquisition: Prosodic memory for pronunciation of target vocabulary by adult non-native English speakers. (Doctoral dissertation, University of Kansas, 1995). Dissertation Abstracts International 45, 332.

22. Zwicky, J. (2000). Wisdom and metaphor. Kentville, NS: Gaspereau Press. 